\title{
Wood Pellet Co-Firing for Electric Generation Source of Income for Forest Based Low Income Communities in Alabama
}

\author{
Ellene Kebede $^{1 *}$, Gbenga Ojumu², Edinam Adozsii ${ }^{1}$ \\ ${ }^{1}$ Department of Agriculture and Environment Science, \\ Tuskegee University, Tuskegee, USA \\ ${ }^{2}$ Department of Agriculture, Nutrition \& Human Ecology, \\ Prairie View A\&M University, Prairie View, USA \\ Email: *Kebede@mytu.tuskegee.edu, oaojumu@pvamu.edu, eadzosii3064@mytu.tuskegee.edu
}

Received February 25, 2013; revised April 4, 2013; accepted May 20, 2013

Copyright (C) 2013 Ellene Kebede et al. This is an open access article distributed under the Creative Commons Attribution License, which permits unrestricted use, distribution, and reproduction in any medium, provided the original work is properly cited.

\begin{abstract}
Alabama imports coal from other states to generate electricity. This paper assessed the direct and indirect economic impacts of wood pellet production to be co-fired with coal for power generation in Alabama. Four sizes of wood pellet plants and regional input-output models were used for the analysis. The results showed that the economic impact increases with the size of the plant. Wood pellet production will have a multiplier effect on the economy especially, forest-related services, retail stores, the health service industry, and tax revenue for the government. Domestic wood pellet production can reduce the use of imported coal, allow the use of local woody biomass, and create economic activities in Alabama's rural communities. Policies that support the production of wood pellet will serve to encourage the use of wood for power generation and support the rural economies.
\end{abstract}

Keywords: Wood Pellet; Electricity; Co-Firing; Coal; Input-Output; Forest Industry

\section{Introduction}

Renewable energy is widely recognized as a substitute for fossil fuels that can reduce the United States' dependence on foreign petroleum and enhance the domestic economy [1]. To date, emphasis has been on producing biofuels from field crops such as corn, sorghum, and oilseeds. Recently, however, advanced biofuels derived from nonfood feed stocks such as switch grass, agricultural residue, and woody biomass have received growing attention and are considered to be the future of the biofuels industry [2]. Regulations grouped under the Renewable Portfolio Standard (RPS) are also designed to increase the production of energy from renewable energy sources. The policy, a result of legislation passed in 1978 under the umbrella of the Public Utility Regulatory Policies Act, mandated increased energy production from renewable resources. The regulations introduced guidelines that a minimum percentage of electricity supply tobe produced from renewable energy sources. Producers with a certified renewable energy generator earn certifi-

\footnotetext{
"Corresponding author.
}

cates for every unit of electricity they produce [3].

The renewable energy certificate is an incentive for electricity producers to use renewable feedstocks in their power generation operations. A good example is the European Union 2020 Energy policy, which is committed to reaching $20 \%$ share of renewable energy sources by 2020 [4]. There is a wider use of co-firing for power generation in Europe to substitute for coal. Imported wood pellets are mainly used for co-firing. Canada was previously the main source of supplier, but currently, the US-based wood pellet industry is gaining a major share. The newest plants in the southeast Georgia, Florida, and Alabama are designed for export markets. The largest wood pellet plant in the world is located in the state of Georgia, USA... Production is exported mainly to The Netherlands and the United Kingdom [5]. As of 2011 a new exportbased wood pellet plant is also under construction in Alabama. Initially, the plant produces 250,000 metric tons of wood pellets per year, and a plant capable of producing 500,000 metric tons per year at full capacity is under construction in Aliceville, Pickens County in Alabama. This plant will start deliveries in 2012 [6]. 
Literature shows that woody biomass can be used for biofuel as liquid transportation fuel and as non-liquid source to generate heat or electricity [7-9]. Wood pellets are used to generate residential heating and commercial power. Residential use in Europe is concentrated mainly in Sweden and Austria and to a lesser extent in Spain and Portugal [10]. The residential wood pellet fuel industry in North America was created in the early 1980s in response to the energy crisis. Currently, almost one million tons of wood pellets are sold each year to heat nearly 500,000 pellet stoves and fireplace in homes in the United States and Canada. Consumption is greatest in the Pacific Northwest and Northeastern states, where wood pellets are manufactured from sawmill and wood product residues and where heating energy requirements are significant [11].

Using wood pellets has the potential to reduce the use of fossil fuels and also attract new business opportunities for investors to consider processing in the rural timberbased communities. States in the Southern US could play a dominant role in the woody biomass industry for generating power. The South is dominated by private forest ownership, and $61 \%$ of the wood residues in the US come from the South [12]. Forest residues and excess mill residues, as well as urban residues, agricultural residues, and dedicated energy crops are assumed to be grown to support energy facilities [13]. Using woody biomass for bioenergy production will create a market for nontraditional sources of fuel such as logging residues, small diameter trees, and thinning residues, which can also be used as feedstocks $[14,15]$. An assessment by [16] of the potential impact of a new bioenergy sector examined using three sources of new energy demands for the South: export, cellulosic ethanol, and biomass electricity. They concluded that because of the established supply chain, relatively low cost and abundant supply of wood, and the consistency of wood's material characteristics, it is reasonable to expect that renewable energy markets would select wood as a preferred biomass feed stock.

Biomass for generating electricity is in its infancy, and economic analysis of biomass feed stock is limited. It is known, however, that co-firing with coal in producing electricity has proven to be technically feasible and cost effective [17]. Alabama Power is the major supplier of electricity in Alabama, and imported coal from other states is used to produce about $85 \%$ of the state's electricity [18]. The company has future plans to substitute renewable sources for fossils fuel, mainly coal. In co-firing, a percentage of biomass is introduced as fuel into an existing coal-fired boiler, often directly blended with the coal itself. Co-firing coal with switch-grass has been tried, and the electricity produced during the tests has been made available for sale to customers through a renewable pricing program $[19,20]$. Co-firing green pine chips with coal was also tested successfully, with one of the findings being that ampere, the current flow of the mill, was related to the percentage of dry wood in the fuel mix [21].

Forestry is an important sector in Alabama. Only nine of 68 counties in the State of Alabama are less than one-half forested with the lowest concentration in the North and the highest in the West Central and Southeast [22]. About $95 \%$ of forest land in Alabama is privately owned, and the area of timber land has increased by $5 \%$ in the 20-year span of 1997 to 2007 [12]. Private forests are composed of $78 \%$ nonindustrial private forest (NIPF) and $16 \%$ forest industry. The industrial forest has declined by $16 \%$, whereas the NIPF increased by $12 \%$ between 1987 and 2002. This indicates a transition from industrial to nonindustrial timber and non-timber uses of forested land. The pulp and paper industry has declined; accordingly, so too has the utilization of forest and forest-processing residues [23]. With the decline of the pulp and paper industry, the utilization of forest and forestprocessing residues could provide opportunities not only to reduce fossil fuel consumption but also to create and sustain employment and income thus contributing to local economies. Past studies have shown the potential effect of woody biomass for cellulosic ethanol production [24]. Cellulosic ethanol is not produced commercially in Alabama, but co-firing of coal with woody biomass has been tested. Given these various factors, the purpose of the present paper is to assess the direct and indirect socioeconomic impacts of small scale wood pellet production for domestic co-firing on forest landowners and rural communities.

\section{Wood Pellet in the South}

The Southeast and South Central US are timber-producing states and consist of more than half of the recoverable logging residues in the USA... Georgia, Alabama, and Mississippi are among the top three states for logging residues from growing stock. As such, the region, these states would be favorable places for commercial development of biomass fueled power generating plants and reducing carbon emissions from coal-generated electricity [25].

Generating electricity through co-firing biomass with coal reduces the out flow of pollutant gases compared with coal alone. An existing power plant facility can blend biomass (up to 5\%) with coal or inject biomass separately (up to 20\%) into the boiler [26]. The Southern Company has partnered with the USDA Forest Service, National Forests in Alabama, Forest Southern Research Station, Auburn University, Forest Products Development, and the CAWACO Resource Conservation and Development Council to test co-firing green wood chips in a boiler. Subsequently, green wood chips were co- 
fired successfully in blends with coal between $8 \%$ and $15 \%$ wood by weight. With $10 \%$ co-firing, boiler efficiency was about the same as coal alone, whereas a slight reduction was observed inefficiency with $15 \%$ wood [21].

Wild fire is a burning problem in many parts of the United States, and studies showed that thinning treatment will reduced wild fire and improve forest health. Alabama has a prescribed burning program to burn fallen branches and trees, low-quality wood, dried grasses, and the like that contribute to wild fire and affect forest health and productivity [23]. Forest thinning could generate feed stock for co-firing and wood pellets for residential and business space heating fuel $[27,28]$. It is estimated that combined bio power use by the industrial sector and electric utilities will meet about $4 \%$ ofenergy demand in 2010 and $5 \%$ in 2020 [13].

Alabama ranks third in the nation for forest and primary mill residues, which come mostly from the West and South regions of Alabama. The lumber market has lost ground since 1995 due to non-wood substitutes, and the paper mill industry, which is concentrated in southern Alabama, has also declined because recycled materials increased to $38 \%$ of the total fiber need by 1998 [26, 29].The availability of wood biomass makes Alabama attractive for producing biomass-based biofuels and bioenergy. In addition, biomass as a feedstock has a positive externality by lowering greenhouse gas emissions. If $\mathrm{CO}_{2}$, as a social cost is incorporated in economic evaluations of generating electricity, logging residues will become a competitive fuel source $[25,30]$.

The woody biofuels markets can create additional revenues to non-industrial private forest landowners and other economic agents that can stimulate employment which could contribute to rural development and benefit local communities [8]. These developments are also expected to contribute to the diversification of local economies and rural communities, in particular those that traditionally depend on timber production [31,32]. A national study using input-output and Policy System Analysis (POLSYS) model estimated the amount of ethanol that can be produced from cellulosic feedstock and the cumulative gain in new jobs, taxes, and reduced petroleum imports [33]. An input-output and CGE model based assessment of the economic impacts of wood biomass as bioenergy feedstock in Florida showed an increase in gross state product, employment, and a slight decrease in gasoline use [34].

A study by [35] estimated the benefits of using logging residues to generate electricity in East Texas and showed that their use reduces site preparation cost. The inputoutput model result showed that the logging residue use and electricity generation together would have a ripple effect on employment and output. Although biomass- based power generation has a relatively high initial investment, the benefits of using local feedstock in the long run will trickledown to the local economy compared to the use of coal for generating power [32]. Research has also shown that the high moisture of the green wood chips and coal mixtures resulted in low mill temperatures and caused a $5 \%$ reduction than its rated maximum power when co-firing [21]. Low moisture content and long storage time are the two advantages of wood pellet. Taken together, the low moisture content and consistent texture make wood pellet a better feedstock for power generation.

\section{The Model}

An input-output (I-O) model was employed to assess the economic impact of wood pellet for power generation in Alabama. I-O models trace commodity flows from producers to intermediates and finally consumers. Industries produce goods and services to meet final demand and purchase raw materials from producers. Producers, in turn, purchase goods and services from other industries. The total industry purchases of commodities, services, value-added, and imports are ultimately equal to the value of the commodities produced. I-O models also provide multipliers that estimate the relationship between the initial effect of a change in final demand and the total effects of that change [36,37]. An I-O model can be written in the matrix form as follows:

$$
\begin{aligned}
& X=A X+Y \\
& X=(I-A)^{-1} Y
\end{aligned}
$$

where $X$ is the vector of total output; A is the matrix of technical coefficients $\left(a_{i j}\right)$, the amount of output of sector $i$ consumed by sector $j$ ); Y is the vector of final demand. Equation (1) wasrearranged to provide Equation (2). The matrix $(I-A)$ is the Leontief matrix and $(I-A)^{-1}$ the Leontief inverse is a matrix of multipliers.

A multiplier for an industry is expressed as a ratio of direct, indirect, and induced effects, and is used to estimate the impacts on output throughout the economy. A Type I multiplier is direct plus indirect effects divided by direct effects. A Type II multiplier is direct plus indirect plus induced impact divided by direct impacts. A Type II multiplier tends to provide a higher estimate than Type I. Type II multipliers are used in the present study.

The multiplier is a coefficient that relates a change in output, employment, and value added as a consequence of change in final demand. The employment multiplier measures the total employment in all sectors in the economy attributable to the job created directly by the sector under consideration. The output multiplier of a sector measures the total production in all sectors of the 
economy that is necessary in meet the demand of the sector under consideration.

In the present study, a regional I-O model that included eight contiguous counties in the South and West regions of Alabama was developed to assess the economic impact on households(value-added employment compensation, proprietor income, other property income) and government (indirect business taxes) and the regional economy. The counties included in the model were: Pickens, Sumter, Greene, Hale, Marengo, Perry, Dallas, and Wilcox. These counties have the highest timberland in Alabama. Greene and Hale counties have 53,000 to 67,000 acres each under timber, and the other six counties have 67,000 to 105,000 acres of timberland each [22].

Table 1 shows the per capita personal income as a percent of state average and the unemployment rate of the counties included in the model. There is slight increase in share of per capita personal income between 2005 and 2010 , but these counties have the lowest per capita personal income in the State of Alabama. They also experience the highest unemployment rate which ranges between $11 \%$ and $22 \%$ compared to state average of $9.5 \%$ in 2010 .

The data for earnings by industry indicates that the government, at the state and federal levels, was the main source of income, accounted for $20 \%$ to $35 \%$ of the total earnings by industry.

This was followed by manufacturing $(10 \%-25 \%)$, health care and social assistance (15\%), and retail trade $(7 \%-8 \%)$. Forestry and logging, which accounted for less than $1 \%$ was reported in four of the eight counties, and none of the counties reported agriculture and forestry support services in 2010. The paper industry was also important in the state during the 1970s and 1980s, but the counties included in the study, except Sumter County, never supported paper manufacturing [38].

Table 1. Per capita personal income as percent and unemployment rate.

\begin{tabular}{cccc}
\hline \multirow{2}{*}{ County } & \multicolumn{2}{c}{ Per capita personal income $^{1}$} & Unemployment rate $^{2}$ \\
\cline { 2 - 4 } & 2005 & 2010 & 2010 \\
\hline Dallas & 82 & 84 & 17.3 \\
Greene & 93 & 95 & 16.9 \\
Hale & 83 & 90 & 12.1 \\
Marengo & 91 & 95 & 12.4 \\
Perry & 76 & 74 & 16.5 \\
Pickens & 79 & 86 & 11.3 \\
Sumter & 68 & 73 & 14.2 \\
Wilcox & 66 & 75 & 21.7 \\
\hline
\end{tabular}

${ }^{1}[39] .{ }^{2}[40]$.
The data for these eight counties were obtained from the 2009 IMPLAN Alabama economic data set [41]. Two IMPLAN sectors were selectedf or the analysis: forestry, forest products, and timber tract production (sector 15) and commercial logging (sector 16). It is also assumed that $25 \%$ and $75 \%$ of the feedstock originates from sectors 15 and 16 , respectively [42].

\section{Model Assumptions}

The study assumes that the demand for wood pellet for co-firing is in place and pine chips are used as a raw material for producing wood pellets. The demand for wood chips was based on the following three assumptions: 1) raw material will be obtained within a 100 -mile radius, which also covers the counties in the model; 2) pine chips have about $40 \%$ moisture content [43]. Based on the literature, co-firing is efficient with $15 \%$ wood [21], the pelleting process reduces the moisture content by about $25 \%$, from $40 \%$ to $15 \%$; and $3 \%$ ) the plants will operate 16 hours per day, a $67 \%$ operational rate for 365 days.

$$
\begin{aligned}
C_{d} & =T_{h} \times P_{s} \\
R_{c} & =C_{d} \times W_{p}
\end{aligned}
$$

where $C d$ is the annual wood chips demand; $T_{h}$ is the tons of pine chips per hour; $P_{s}$ is the plant size; $F_{c}$ is the cost of raw material; and $W_{p}$ the price of pine chips [44]. The price includes transportation costs within the 100mile radius.

Plant size affects the efficiency and feasibility of a plant. The efficiency of producing pellets increases with size, and larger pellet producers are often more profitable than smaller producers [45]. Capital investment costs per ton decrease with an increase incapacity, and pellet mills are cost effective when they produce more than 10 tons per hour $(\mathrm{t} / \mathrm{h})$ of pellets $[46,47]$. This study shows the economic impact of four different plant sizes expressed in tons of wood pellet per year: $10 \mathrm{t} / \mathrm{h}$ or 50,000 tons per year; $20 \mathrm{t} / \mathrm{h}$ or 100,000 tons per year; and $40 \mathrm{t} / \mathrm{h}$ or 200,000 tons per year plants and the current export-based production with approximately $95 \mathrm{t} / \mathrm{h} 500,000$ tons per year. The estimated annual wood chip cost for different plant sizes were imported to the regional input/output model.

\section{Results and Discussions}

The South and West regions of Alabama have a large forested area and are experiencing a higher level of unemployment accompanied with lowest per capita personal income in the State and can benefit from the establishment of woody biomass processing plants like wood pellets. As indicated by the input-output results, the 10 industries that will benefit from the wood pellet produc- 
tion are the main suppliers and related support services. The top three sectors that accounted for $70 \%$ of the employment and income are: commercial logging (sector 16); forestry, forest products and timber tract production (sector 15), and support activities for agriculture and forestry (sector 18). In addition, the food and beverage services sector will benefit from the increase in demand and income in the economy. The other sectors that gain from the wood pellet production are: private household operations; nursing and residential care facilities; retail stores for food and beverages; wholesale trade businesses; and health services.

The ripple effect is associated with the demand from these industries to supply services required by the wood pellet industry. This is captured in the Type II employment and output multipliers. Table 2 compares the multipliers of sector 15 and 16 with the paper manufacturing sector (sector 105). The employment multiplier is what every job created in the sector will create in other sectors of the economy. Sector 15 had a larger employment multiplier (4.533) than sector 16 (1.39), generating more overall jobs for each job created in the sector. A job created in the forest/forest related sector will create 4.533 jobs in the economy, whereas the logging sector will create 1.39 jobs in the economy for each job created in the sector. The output multiplier for the sectors, therefore, is not significantly different.

The multipliers apply to any size plants, but the total effect will vary with the plant size.

The results of the economic impact of the four plant sizes analyzed are provided in Tables 3-6. Based on past studies, the increase in plant size will enhance cost effectiveness, and for this analysis an increase in the plant size increased the total impact on the regional economy. The increase in plant size from $10 \mathrm{t} / \mathrm{h}$ to $40 \mathrm{t} / \mathrm{h}$ increased labor income, value added, and output by $300 \%$, and increased

Table 2. Type II employment and output multipliers.

\begin{tabular}{ccc}
\hline Sector & Employment Multiplier Output Multiplier \\
\hline Commercial Logging & 1.390 & 1.499 \\
$\begin{array}{c}\text { Forest Products and } \\
\text { Timber Tract Production }\end{array}$ & 4.533 & 1.655 \\
\hline
\end{tabular}

Table 3. The results of the economic impact of 10 tons per hour wood pellet plant.

\begin{tabular}{|c|c|c|c|c|c|}
\hline $\begin{array}{l}\text { Type of } \\
\text { Impact }\end{array}$ & $\begin{array}{l}\text { Direct } \\
\text { Effect }\end{array}$ & $\begin{array}{l}\text { Indirect } \\
\text { Effect }\end{array}$ & $\begin{array}{l}\text { Induced } \\
\text { Effect }\end{array}$ & $\begin{array}{l}\text { Total } \\
\text { Effect }\end{array}$ & $\begin{array}{c}\text { Indirect }+ \text { Induce/ } \\
\text { total Effect }\end{array}$ \\
\hline Employment & 19 & 11.4 & 5.9 & 36.3 & 0.48 \\
\hline $\begin{array}{l}\text { Labor Income } \\
\text { (M \$) }\end{array}$ & 1.04 & 0.39 & 0.17 & 1.61 & 0.35 \\
\hline $\begin{array}{l}\text { Value Added } \\
\qquad \text { (M \$) }\end{array}$ & 1.41 & 0.51 & 0.35 & 2.27 & 0.38 \\
\hline Output (M \$) & 3.33 & 0.96 & 0.59 & 4.87 & 0.32 \\
\hline
\end{tabular}

Table 4. The results of the economic impact of 20 tons per hour wood pellet plant.

\begin{tabular}{|c|c|c|c|c|c|}
\hline Type of Impact & $\begin{array}{l}\text { Direct } \\
\text { Effect }\end{array}$ & $\begin{array}{l}\text { Indirect } \\
\text { Effect }\end{array}$ & $\begin{array}{l}\text { Induced } \\
\text { Effect }\end{array}$ & $\begin{array}{l}\text { Total } \\
\text { Effect }\end{array}$ & $\begin{array}{l}\text { Indirect }+ \\
\text { Induce/total } \\
\text { Effect }\end{array}$ \\
\hline Employment & 38 & 22.8 & 11.7 & 72.51 & 0.48 \\
\hline $\begin{array}{l}\text { Labor Income } \\
\text { (M \$) }\end{array}$ & 2.08 & 0.79 & 0.34 & 3.22 & 0.35 \\
\hline $\begin{array}{l}\text { Value Added } \\
\qquad \text { (M \$) }\end{array}$ & 2.82 & 1.02 & 0.71 & 4.55 & 0.38 \\
\hline Output (M \$) & 6.66 & 1.91 & 1.18 & 9.74 & 0.32 \\
\hline
\end{tabular}

Table 5. The results of the economic impact of 40 tons per hour wood pellet plant.

\begin{tabular}{cccccc}
\hline Type of Impact & $\begin{array}{c}\text { Direct } \\
\text { Effect }\end{array}$ & $\begin{array}{c}\text { Indirect } \\
\text { Effect }\end{array}$ & $\begin{array}{c}\text { Induced } \\
\text { Effect }\end{array}$ & $\begin{array}{c}\text { Total } \\
\text { Effect }\end{array}$ & $\begin{array}{c}\text { Indirect }+ \\
\text { Induce/total } \\
\text { Effect }\end{array}$ \\
\hline $\begin{array}{c}\text { Employment } \\
\text { Labor Income } \\
\text { (M \$) }\end{array}$ & 75.9 & 45.6 & 23.5 & 145 & 0.48 \\
$\begin{array}{c}\text { Value Added } \\
\text { (M \$) }\end{array}$ & 5.64 & 2.04 & 1.41 & 9.09 & 0.38 \\
Output (M \$) & 13.31 & 3.82 & 2.35 & 19.49 & 0.32 \\
\hline
\end{tabular}

Table 6. The results of the economic impact of 95 tons per hour wood pellet plant.

\begin{tabular}{cccccc}
\hline Type of Impact & $\begin{array}{c}\text { Direct } \\
\text { Effect }\end{array}$ & $\begin{array}{c}\text { Indirect } \\
\text { Effect }\end{array}$ & $\begin{array}{c}\text { Induced } \\
\text { Effect }\end{array}$ & $\begin{array}{c}\text { Total } \\
\text { Effect }\end{array}$ & $\begin{array}{c}\text { Indirect }+ \\
\text { Induce/total } \\
\text { Effect }\end{array}$ \\
\hline $\begin{array}{c}\text { Employment } \\
\text { Labor Income } \\
\text { (M \$) }\end{array}$ & 158 & 95 & 49 & 302 & 0.48 \\
$\begin{array}{c}\text { Value Added } \\
\text { (M \$) }\end{array}$ & 117.37 & 42.76 & 14.34 & 133.83 & 0.35 \\
Output (M \$) & 276.87 & 79.45 & 48.91 & 405.33 & 0.32 \\
\hline
\end{tabular}

to $800 \%$ when the plant size increases to $95 \mathrm{t} / \mathrm{h}$. Most of the employment was created in the commercial logging and forestry-related sectors. These sectors had an important indirect and induced impact on the economy especially in the 10 major sectors. The share of the indirect and induced to total effect showed that $48 \%$ of the employment, $35 \%$ of the labor income, $38 \%$ of the value added, and $32 \%$ of the total output resulted from the indirect and induced effects.

Distribution of value added showed that employment compensation (wages and salaries) accounted for 57\%; other property type income (rental) accounted for $18 \%$; proprietor income accounted for $16 \%$; and indirect business taxes to the government accounted for $10 \%$ of the value added. The logging industry uses heavy machinery and equipment and the higher compensation could be associated the skilled manpower employed by the log- 
ging industry.

Notably, the region has the highest forest cover where forestry logging is less than $1 \%$ of income generated in the economy. Establishing a wood pellet plant could stimulate the forest industry and commercial logging, which could increase the income earned from forestry.

Furthermore, it could be an incentive to the establishment of the forest-related services sector that is not currently making a significant contribution to the regional economy.

\section{Conclusion}

Woody biomass is a major resource that could be used as a substitute for coal ingenerating electricity in Alabama. Wood pellet is not used widely for power generation in the United States, especially in the South. However, the State of Georgia has one of the largest wood pellet plants in the world, and Alabama has one wood pellet plant that produces products for export. The present study estimated the socioeconomic impacts of small-scale wood pellet plants for co-firing in power generating plants in the south and west regions of Alabama. Alabama Power Company, the major electricity supplier in the state, has a coal-based plant in Greene County with a generating capacity of $1,220,000 \mathrm{~kW}$ [20]. Wood pellet plants in the counties studied will be within a good proximity to the power generation plant. The company has successfully tested co-firing coal with green wood, and the results showed that wood can be co-fired up to $15 \%$, but moisture content affects the ampere, the current production. Wood pellet has the added advantage of low moisture and a consistent texture to mitigate the loss of current output. The present paper assumed demand levels for wood pellet and assessed the economic impact of wood pellet for co-firing for generating power. The study tested four sizes of wood pellet plants and showed that the impact increases with the increase in plant size. Most of the employment, value added, and output will be generated in the commercial logging sector and forestry and forestproduction tracts sector. These sectors will create demand for skilled manpower related to logging, equipment handlers, and transportation as well as provide income to the owners of forested land. The high employment multiplier showed that using wood pellets for co-firing will generate additional employment in the service sectors. The increase in demand for wood will encourage the use of forest residues and other biomass that have not been used to date that could generate income to property owners. The economic impact of the current large size plant for export is larger than the small-scale plants, but because it is export-oriented, its impact on reducing coal import and carbon emission in the state is none. The present study has shown that small-scale wood pellet plants can play a triple role in the economy, enhance the eco- nomic activity of the region, reduce the use of imported coal, and reduce $\mathrm{CO}_{2}$ emissions. The use of wood biomass might be expensive, but studies $[25,30]$ have shown that if the social cost of $\mathrm{CO}_{2}$ emissions is considered, woody biomass can be competitive for producing electricity. Given the current $10 \%$ co-firing [21], which is regarded as efficient, the use of wood pellet will reduce coal import and carbon emission and generate economic activity in the region. In conclusion, the use of woody biomass for generating power will have a long-term economic impact on the community and the region. These benefits to the region and the community could be the basis for government support for developing the wood pellet sector.

\section{Acknowledgements}

The paper was part of a study funded by USDA Office of the Chief Economist/Energy Policy and New Uses.

\section{REFERENCES}

[1] B. Antizar-Ladislao and J. L. Turrion-Gomez, "SecondGeneration Biofuels and LocalBioenergy Systems," Biofuels Bioproducts and Biorefining, Vol. 2, No. 5, 2008, pp. 455-469. doi:10.1002/bbb.97

[2] USDA, "A Regional Roadmap to Meeting the Biofuels Goals of the Renewable Fuel Standard by 2022," USDA Biofuels Strategic Production Report, 2012.

http://www.usda.gov/documents/USDA_Biofuels_Report 6232010

[3] K. S. Cory and B. G. Swezey, "Renewable Portfolio Standards in the States: Balancing Goals and Implementation Strategies," National Renewable Energy Laboratory, Technical ReportNREL/TP-670-41409, 2007.

[4] European Commission, "Energy 2020, a Strategy for Competitive, Sustainable and Secure Energy," Publications Office of the European Union, European Union Luxembourg, 2011.

[5] Renewable Energy World, "World's Largest Wood Pellet Plant to Feed REW Europe Power Plants," 2012. http://www.renewableenergyworld.com

[6] Westervelt Company, "Aliceville Selected for Fuel Pellet Production Facility," 2012. http://westervelt.com/westervelt-newsroom/pressreleases

[7] R. C. Brown, "Biorenewable Resources: Engineering New Products from Agriculture," Blackwell Publishing, Iowa State Press, Ames, 2003

[8] A. P. C. Faaij and J. Domac, "Emerging International Bio-Energy Markets and Opportunities for Socio-Economic Development," Energy for Sustainable Development, Vol. 1, No. X, 2006, pp. 7-19. doi:10.1016/S0973-0826(08)60503-7

[9] B. Jackson, R. Schroeder and S. Ashton, "Pre-Processing and Drying Woody Biomass. Sustainable Forestry for Bioenergy and Bio-Based Products," Fact Sheet 2007, pp. 141-144. 
[10] R. Jannasch, R. Samson, A. de Maio, T. Adams and C. H. Lem, "Changing the Energy Climate: Clean and Green Heat from Grass Biofuel Pellets," Energy Probe, 2001. www.energyprobe.org

[11] H. Spelter and D. Toth, "North America's Wood Pellet Sector, "United States Department of Agriculture, Forest Service," Forest Products Laboratory Research Paper FPL-RP-656, 2009, pp. 5-23.

[12] W. B. Smith, P. D. Miles, C. H. Perry and S. A. Pugh, "Forest Resource of the United States, 2007," General Technical Report-WO-78, United States Department of Agriculture Forest Service, 2012.

[13] R. D. Perlack, L. L. Wright, A. F. Turhollow, R. L. Graham, B. J. Stokes and D. C. Erbach, "Biomass as Feedstock For a Bioenergy and BioproductsIndustry: The Technical Feasibility of a Billion-Ton Annual Supply," US Department of Agriculture, DOE/GO-102005-2135, ORNL/TM, 2012.

[14] E. M. White, "Woody Biomass for Bioenergy and Biofuels in the United States," United States Department of Agriculture, Forest Service, Technical Report PNWGTR-825, 2012.

[15] B. L. Polagye, K. T. Hodgsonb and P. C. Maltea, “An Economic Analysis of Bio-Energy Options Using Thinning from Overstocked Forests," Biomass and Energy Biomass, Vol. 31, No. 2-3, 2007, pp. 105-125. doi:10.1016/j.biombioe.2006.02.005

[16] G. Comatas and J. Shumaker, Cross Reference Wear et al. 2007, 2009.

[17] S. Nienow, K. McNamara, A.Gillespie and A. Preckel, "A Model for the Economic Evaluation of Plantation Biomass Production for Co-Firing with Coal in Electricity Production," Agricultural and Resource Economics Review, Vol. 1, No. 28, 1999, pp. 106-118.

[18] Energy Information Administration, “Alabama, Overview and Analysis 2009," 2012.

http://www.eia.gov/state/state-energy-profiles.cfm?sid=A L

[19] Southern Company, "Southern Company and Renewable Energy, Overview 2007," 2012.

http://southerncompany.com/planetpower/pdfs/renewable _energy.pdf

[20] Alabama Power, "Power Generating Plants," 2012. http://www.alabamapower.com/about/plants.asp

[21] D. Boylan, K. Roberts, B. Zemo and T. Johnson, "Phase 2 Co-Firing Testing of Wood Chips at Alabama Power's Plant Gadsden 2008," 2012. www.cawaco.org/biomass/Phase2report.pdf

[22] University of Alabama, "Total Woodland Areas by County 2007," 2012. http://alabamamaps.ua.edu/

[23] B. W. Smith, P. D. M. Patrick, J. S. Vissage and S. A. Pugh, "Forest Resources of the United States, 2002," A Technical Document Supporting the USDA Forest Service an Update of the RPA Assessment, North Central Research Station, Forest Service-US Department of Agriculture, 2004.

[24] C. Bailey, J. F. Conner, J. F. Dyer and L. Teeter, "Assessing the Rural Development Potential of Lignocellu- losic Biofuels in Alabama," Biomass and Bioenergy, Vol. 35, No. 4, 2011, pp. 1407-1417. doi:10.1016/j.biombioe.2010.11.033

[25] J. Gan and C. T. Smith, "A Comparative Analysis of Woody Biomass and Coal for Electricity Generation under Various $\mathrm{CO}_{2}$ Emission Reductions and Taxes," Biomass and Bioenergy, Vol. 30, No. 4, 2006, pp. 296-303.

[26] D. N. Wear, D. R. Carter and J. Prestemon, "The US South's Timber Sector in 2005. A Prospective Analysis of Recent Change," USDA Forest Service Southern Research Station, Asheville, 2007.

[27] K. E. Skog and R. J. Barbour, "Estimating Woody Biomass Supply from Thinning Treatments to Reduce Fire Hazard in the US West," Proceedings RMRS-P-41, USDA Forest Service, 2006, pp. 657-672.

[28] D. G. Neary and E. J. Z. Elaine, "Forest Bioenergy System to Reduce the Hazard of Wildfires: White Mountains, Arizona," Biomass and Bioenergy, Vol. 31, No. 9, 2007, pp. 638-645. doi:10.1016/i.biombioe.2007.06.028

[29] A. Millbrandt, "A Geographic Perspective on the Current Biomass Resource Availability in the United States," National Renewable Energy Laboratory, Technical Report NREL/TP-560-39181, 2005, pp. 18-27.

[30] M. Gronowska, S. Joshi. and H. L. MacLean, "A Review of US and Canadian Biomass Supply Studies," BioResources, Vol. 4, No.1, 2009, pp. 341-369.

[31] J. Bliss and C. Bailey, "Pulp, Paper, and Poverty: Forest-Based Rural Developmentin Alabama, 1950-2000," In: R. Lee and D. Field, Eds., Communities and Forests: Where People Meet the Land, Oregon State University Press, Corvallis, 2005, pp. 138-158.

[32] J. Domac, J. Richard and S. Risovic, "Socio-Economic Drivers in Implementing Bioenergy Projects," Biomass and Bioenergy, Vol. 28, No. 2, 2005, pp. 97-106. doi:10.1016/j.biombioe.2004.08.002

[33] D. G. De La Torre Ugarte, B. C. English and K. Jensen, "Sixty Billion Gallons by 2030: Economic and Agricultural Imparts of Ethanol and Biodiesel Expansion," American Journal of Agricultural Economics, Vol. 89, No. 5, 2007, pp. 1290-1295. doi:10.1111/j.1467-8276.2007.01099.x

[34] A. W. Hodges, J. S. Thomas and M. Rahmani, "Economic Impacts of Expanded Woody Biomass Utilization on the Bioenergy and Forest Products Industries in Florida," Institute of Food and Agricultural Sciences Food, Gainesville, 2012.

www.fred.ifas.ufl.edu/economic-impact-analysis/pdf/Wo ody-Biomass-Utilization.pdf

[35] J. B. Gan and T. C. Smith, "Co-Benefits of Utilizing Logging Residues for Bioenergy Production: The Case for East Texas, USA," Biomass and Bioenergy, Vol. 31, No. 9, 2007, pp. 623-630. doi:10.1016/j.biombioe.2007.06.027

[36] R. E. Miller and P. D. Blair, "Input-Output Analysis Foundation and Extension," Prentice Hall, Inc., Upper Saddle River, 1985.

[37] J. D. G. Hewing, "Regional Input-Output Analysis," SAGE Publications, Beverly Hills, 1985. 
[38] Bureau of Economic Analysis, "Personal Income and Earning by Industry," 2012.

http://www.bea.gov/regional/index.htm

[39] University of Alabama, "Income Poverty and Employment," 2012. http://cber.cba.ua.edu/

[40] Alabama Department of Industrial Relations, "Unemployment Statistics," 2012. http://www2.dir.state.al.us/LAUS/default.aspx

[41] Minnesota IMPLAN Group Inc., "Alabama Economic Data," Hudson, 2009.

[42] University of Alabama, "Assessment of Wood-Based Syngas Potential for Use in Combined Cycle Power Plants in Alabama," Draft Prepared by University Center for Economic Development, University of Alabama, Tuscaloosa, 2012.

[43] M. D. Gibson, "Moisture Content and Specific Gravity of the Four Major Southern Pines under the Same Age and Site Conditions," Wood and Fiber Science, Vol. 18, No. 3,
1986, pp. 428-435.

[44] T. Mart-South, "A Quarterly Report of the Market Conditions for Timber Products of the US South," 2012. http://www.timbermart-south.com/pdf/2Q2011news.pdf

[45] A. Wolf, A. Vidlund and E. Andersson, "Energy-Efficient Pellet Production in the ForestIndustry-A Study of Obstacles and Success Factors," Biomass and Bioenergy, Vol. 30, No. 1, 2006, pp. 38-45. doi:10.1016/j.biombioe.2005.09.003

[46] S. Mani, S. Bi, X. Sokhansanj and A. Turhollow, "Economics of Producing Fuel Pellets from Biomass," Applied Engineering in Agriculture, Vol. 22, No. 3, 2006, pp. 421-426.

[47] P. Porter, J. Barry, R. Samson and M. Doudlah, "Growing Wisconsin Energy: A Native Grass Pellet Bio-Heat Roadmap for Wisconsin," Agrecol, 2012.

http://datcp.wi.gov/uploads/Business/pdf/22061Agrecol.p df 